\title{
Anticancer potential of Chenopodium album leaf extract against Ehrlich ascites carcinoma cells in Swiss albino mice
}

\author{
Sohel Rana ${ }^{1 *}$ (D), Shakila Rahman², Samiron Sana ${ }^{3}$, Tonmoy Kumar Biswas ${ }^{4}$, Abu Kayes Md. Hashem5, \\ Shahnaz Parvin ${ }^{5}$ and Kishor Mazumder ${ }^{3}$
}

\begin{abstract}
Background: Chenopodium album (Family: Amaranthaceae) is a nutritive herb mainly found in Bangladesh and had reported that it is having different bioactive phytochemicals including polyphenols. It has a great popularity for it is traditionally used as a medicine against microorganisms, inflammation, and cancer. We designed this experiment to explore the in vivo anticancer effects of C. album leaf extract against Ehrlich ascites carcinoma (EAC) cells in Swiss albino mice.

Results: Administration of C. album leaf extract at concentration $200(\mathrm{mg} / \mathrm{kg})$ and $400(\mathrm{mg} / \mathrm{kg})$ showed 30.60\% and $41.80 \%$ cell growth inhibition respectively that were statistically significant $\left({ }^{* * *} P<0.001\right)$ and may lead to apoptosis, and the number of apoptotic cells were $37.5 \pm 6.22,54.67 \pm 4.76$ respectively $\left.{ }^{* * *} P<0.001\right)$. Plant extract at concentration $200(\mathrm{mg} / \mathrm{kg})$ and $400(\mathrm{mg} / \mathrm{kg})$ increased life span $22.27 \%$ and $51.07 \%$ respectively. Tumor weight decreased $18.50 \pm 2.59 \mathrm{~g}, 13.67 \pm 2.25 \mathrm{~g}$ respectively compared to the control group, and results were statistically significant (*** $<0.001)$. Treatment with plant extract $200(\mathrm{mg} / \mathrm{kg})$ and $400(\mathrm{mg} / \mathrm{kg})$ restored all biochemical parameters including hemoglobin content, white blood cell (WBC) count, and red blood cell (RBC) count of EAC cells bearing Swiss albino mice.

Conclusion: Our current findings may suggest that C. album leaf extract showed potent anticancer activity through cell growth inhibition and apoptosis, increased mean survival time, decreased tumor weight, and restored all the biochemical parameters and stimulation of host immunity. As a result, the C. album leaf has taken into consideration as a potent source of bioactive compounds in cancer chemotherapy.
\end{abstract}

Keywords: Chenopodium album, Cell growth inhibition, Apoptosis, Antioxidants, Antitumor, Anti-proliferation

\section{Background}

Cancer is a complex multifactorial cell disease; the unusual cellular proliferation can represent that. Both cancer growth and advancement mainly depend on the cellular aggregation of many genetics and epigenetics events [1]. Because of the alteration of the tumor suppressor gene, oncogene, and microRNA gene cancer may occur. Cancer may also occur because of the unusual net accumulation

\footnotetext{
* Correspondence: sohelrana3940@gmail.com

${ }^{1}$ Department of Pharmacy, Faculty of Biological Science and Technology, Jashore University of Science and Technology, Jashore 7400, Bangladesh Full list of author information is available at the end of the article
}

of distinctive cells originating from additional proliferation, deficient apoptosis, or by both [1].

Many reactive oxygen species (ROS) produced from both intracellular and extracellular sources that react with cellular proteins and DNA as a consequence unstable genomes, base alteration, and genetic changes occur. The normal apoptotic signaling process including uncontrolled cell proliferation and tumor formation alter because of such kind of molecular modification [2]. Studies suggest that there has a rigid relationship between the imbalance of antioxidant levels and the growth of several fatal diseases like neurological disease, 
cardiovascular disorder, aging, and cancer. The naturally got products considered traditionally as the ample source of phytochemical having potent bioactivities against several fatal diseases such as cancer and infectious disease [2]. Statistics showed that currently more than $60 \%$ of the anticancer drugs related to herbal products as their origin [2]. As a result, natural sources including medicinal plants can be a promising source of potent bioactive drugs against cancer.

Chenopodium album (Family: Amaranthaceae) is a weed widely allotted including south Asia, Bangladesh, and has common names such as pigweed and lambs' quarters. (Bengali: Chandanbethu). In Bangladesh, it is taken as vegetables in winter. The C. album L. has various phytochemicals including total phenols, saponins, alkaloids, flavonoids, glycosides, essential oils, trigonelline, chenopodine, potassium, and vitamin $C[3,4]$. The plant has various pharmacological potentials like antioxidation, anticancer, antipruritic, antinociceptive antiinflammatory, antiviral, antibacterial, antifungal [5-7], and also some traditional uses including purgative, helminthic, and blood purifier and tonic [3]. We designed this experiment to explore the anticancer potentials of $C$. album leaf extract against EAC cell bearing Swiss albino mice.

\section{Methods}

\section{Chemicals and reagents}

Reagents and chemicals used for this experiment are all of reagent grade. Trypan blue dye, DAPI, PBS: phosphatebuffered saline, methanol, and ethanol (Sigma, USA); DMSO (Merck, Germany); Solo ${ }^{\text {тм }} 0.9 \%(\mathrm{NaCl})$ IV Infusion (Square Pharmaceuticals Ltd, Bangladesh); Vacutainer ${ }^{\circ}$ EDTA Tubes (Thomas Scientific).

\section{Collection and identification of plant material}

Fresh, young, and mature C. album leaves were collected from Jashore, Bangladesh, in July 2019. The Naimur Rahman (taxonomist and senior scientific officer at National Herbarium, Dhaka, Bangladesh, identified and authenticated the leaves). The accession number for the plant is 46989 .

\section{Preparation of plant extract}

To remove dirt, collected fresh leaves of the C. album were washed with cold and then hot water to remove any kind of organism. The leaves were dried in a shaded area for 15 days (at room temperature, $25 \pm 2{ }^{\circ} \mathrm{C}$ ) to prevent photo-oxidation of bioactive components and then ground into a fine powder. The leaves fine powder (500 g) extracted by using methanol (99.8\%) (3 L) at room temperature $\left(25 \pm 2{ }^{\circ} \mathrm{C}\right)$ for 15 days with agitation three times in a day. Finally, filtration performed by using cotton and then no.1 Whatman filter paper. The filtrate is then concentrated by using a rotary evaporator and finally air dried. The extract yield was $6.78 \%(\mathrm{w} / \mathrm{w})$ with methanol.

\section{Animals}

Adult male Swiss albino mice (8-9 weeks old), weighing 28-30 g, were taken for the experiment. We collected mice from the department of pharmacy, Jahangirnagar University, Dhaka, Bangladesh. The animals were kept in standard environmental conditions including relative humidity (RH) $55 \pm 5 \%$ and temperature $(22 \pm 2){ }^{\circ} \mathrm{C}$ in the Pharmacology lab. The $24 \mathrm{~h}$ were divided into $12 \mathrm{~h}$ lightdark cycles for 1 week in the animal house for adaptation to a new climate before the experiment. The animals took tap water ad libitum and standard laboratory food. After the completion of the experiment, all the remaining living mice that were used under this laboratory experiment euthanized and anesthetized for their normal death.

The study protocol was approved by the institutional animal ethical committee of Jashore University of Science and Technology, Jashore, Bangladesh. This research work was approved by the Ethical Review Committee of Research cell of Jashore University of Science and Technology, Jashore7408, Bangladesh (Ref: ERC/FBS/JUST/2019-16).

\section{Tumor cells}

Ehrlich ascites carcinoma (EAC) cells were inoculated by Professor Dr. Abu Reza, Protein Science Lab, Department of Genetic Engineering and Biotechnology, University of Rajshahi, Rajshahi-6205, Bangladesh, and EAC cells were maintained by weekly intraperitoneal (i.p.) inoculation of $1 \times 10^{5}$ cells/mouse in the laboratory.

\section{Determination of median lethal dose $\left(\mathrm{LD}_{50}\right)$}

The median lethal dose $\left(\mathrm{LD}_{50}\right)$ value was determined by the following conventional methods with minor modifications [8]. The C. album leaf extract was dissolved in $0.1 \%(\mathrm{v} / \mathrm{v})$ dimethylsulfoxide (DMSO) with $0.9 \%$ normal saline for performing the experiments and injected intraperitoneally to six groups of mice $(n=6)$ at various doses $(100,200,400,800,1600,3200 \mathrm{mg} / \mathrm{kg})$. The median lethal dose $\left(\mathrm{LD}_{50}\right)$ was determined by taking a record of mortality at the end of the $24 \mathrm{~h}$ experiment.

\section{Experimental design}

Total mice were subdivided into four groups, in where group I, group II, group III, and group IV were considered and treated with negative control, positive standard, $200(\mathrm{mg} / \mathrm{kg})$, and $400(\mathrm{mg} / \mathrm{kg})$ respectively. Group I received only $0.1 \%(\mathrm{v} / \mathrm{v})$ DMSO (dimethylsulfoxide) and $0.9 \%$ normal saline and treated as a control group, group II received standard drug vincristine sulfate $0.3 \mathrm{mg} / \mathrm{kg}$ and treated as a standard group, group III and IV received 200 and $400(\mathrm{mg} / \mathrm{kg})$ C. album leaf extract to identify the potentiality of plant extract as an anticancer 
drug at lower concentration and treated as experiment group. Treatment of mice was initiated at the end of the $24 \mathrm{~h}$ of tumor cells inoculation through intraperitoneally (i.p.) by Professor Dr. Abu Reza (Department of Genetic Engineering and Biotechnology, University of Rajshahi, Rajshahi-6205, Bangladesh).

\section{Measurement of cell growth inhibition}

Cell growth inhibition was measured through conventional methods with minor modifications [2]. Mice of each group $(n=6)$ were inoculated as $1 \times 10^{5}$ EAC cells in $1 \mathrm{~mL}$ concentration $(10 \mu \mathrm{L})$ with a thin $(5 \mathrm{~mL})$ syringe. Treatment was started at the end of the $24 \mathrm{~h}$ of EAC cell introduction and carried out 6 days. On the 7 th day, the animals were anesthetized using chloroform and from the intraperitoneal cavity of mice, cancer cells were collected, and cells were then diluted with $0.9 \% \mathrm{NaCl}$ saline water. By using trypan blue stain, different slides were prepared to count viable cells. Finally, viable cells were counted under the microscope using hemocytometer through the following equation:

\section{$\%$ Cell Growth Inhibition $=(1-\mathrm{Tw} / \mathrm{Cw}) \times 100$}

where,

$\mathrm{Tw}=$ mean number of EAC cells in the treated mice

$\mathrm{CW}=$ mean number of EAC cells in the control mice

\section{Apoptosis determination by DAPI staining}

Apoptosis determination by DAPI staining of EAC cell was conducted by the conventional methods with minor modifications [2]. On the 7th day, $1 \mathrm{~mL}$ EAC cells were collected from each group of mice, and centrifugation was performed for $2 \mathrm{~min}$ at $705 \times g$ and the plate was washed with PBS (phosphate buffer solution) each time. The obtained cells were then incubated in dark for 10 min with $5 \mu \mathrm{L}$ DAPI staining solution. The phosphate buffer solution (PBS) was then added to the DAPI containing pellets. The mixer then centrifuged for $2 \mathrm{~min}$ at $705 \times g$. The microscopic slide was loaded with $10 \mu \mathrm{L}$ of the supernatant and $200 \mu \mathrm{L}$ phosphate buffer solution with the obtained pellet. The morphological change was observed through a fluorescence microscope (Optika, Italy) of EAC cancerous cells.

\section{Assessment of average tumor weight and mean survival time}

Assessment of average tumor weight and mean survival time of EAC cell bearing Swiss albino mice was conducted by the conventional methods with minor modifications $[9,10]$. At the end of the $24 \mathrm{~h}$ of tumor cells, introduction and treatment were continued for 15 days. The tumor weight (g) was assessed through a daily basis weight change record. The survival time of mice was noted and stated as MST (mean survival time) in days and $\%$ increase of life span was calculated through the following equation:

$$
\begin{gathered}
\text { Mean survival time : } \sum \frac{\text { Survival time }(\text { days }) \text { of each group mouse }}{\text { Total number of mice }} \\
\% \text { increase in life span }=\left(\frac{\text { MST of Treated Group }}{\text { MST of Control Group }}-1\right) \times 100 \\
\text { Average Tumor Weight }(\%)=\left(\frac{\text { Tumour weight in mg of each mouse group }}{\text { Total Number }}\right) \times 100
\end{gathered}
$$

where Tumor weight in $\mathrm{mg}=$ weight after treatment and weight before treatment of mouse

\section{Monitoring of the hematological parameters}

The experiment was performed to conduct the hematological profile of EAC cell bearing mice by conventional methods with minor modifications [10]. To assess the anticancer effects of $C$. album leaf extract for the hematological profile including $\mathrm{RBC}, \mathrm{WBC}$, and hemoglobin content. Treatment of mice was initiated at the end of the $24 \mathrm{~h}$ of EAC cells inoculation and carried out 6 days. On the 7th day, blood was collected from six mice of each group by tail puncturing and preserved in EDTA tubes. Through the centrifugation, serum was separated from plasma at $2352 \times g$ for $10 \mathrm{~min}$ and blood was analyzed using Bioanalyzer (Microlab 200) with the help of commercial kits (Atlas Medica, UK).

\section{Brine shrimp lethality bioassay}

Brine shrimp lethality bioassay of Chenopodium album leaf extract was conducted by the conventional method with minor modification [11]. Brine shrimps (Scientific name: Artemia salina leach) nauplii considered as a test organism for this study. For this experiment, $16 \mathrm{mg}$ of the test sample (extract) was dissolved in $200 \mu \mathrm{L}$ of pure dimethylsulfoxide (DMSO) and finally, the volume was made to $20 \mathrm{~mL}$ with seawater and obtained stock solution with concentration $800 \mu \mathrm{g} / \mathrm{mL}$. Then the solutions of various concentrations $(400,200,100,50,25,12.5$, $6.25 \mu \mathrm{g} / \mathrm{mL}$ ) were obtained through serial dilution. A total of $2.5 \mathrm{~mL}$ of seawater containing pre-marked vials and there $2.5 \mathrm{~mL}$ of plant extract solution was added to adjust $5 \mathrm{~mL}$ final volume. Each premarked vial contains 10 live brine shrimp nauplii. The experiment was performed twice. At the end of the $24 \mathrm{~h}$, a magnifying glass was used for the counting and recording and the numbered of survived nauplii in each vial.

\section{Statistical analysis}

The obtained results were expressed as mean \pm standard deviation (SD). Statistical analysis was performed by one-way ANOVA followed by Bonferroni test where * $P$ $<0.05, * P<0.01$, and ${ }^{* * *} P<0.001$ were considered statistically significant compared to the control group using 
SPSS software (16, New York, USA). The graph was prepared by using the Graph Pad Prism 8.0.1 version software.

\section{Results}

Determination of median lethal dose $\left(\mathrm{LD}_{50}\right)$

The median lethal dose $\left(\mathrm{LD}_{50}\right)$ value of $C$. album leaf extract was evaluated in Swiss albino mice and showed no toxicity, including no physical and behavioral changes were observed in animals after $24 \mathrm{~h}$ of the experiment on Swiss albino mice as shown in Fig. 1.

\section{Determination of cell growth inhibition}

Cell growth inhibition properties of C. album leaf extract are represented in Fig. 2. The number of viable EAC cells in all treated groups was reduced as compared to the control group. According to the presented data in Fig. 2, C. album leaf extract that has comparatively higher growth inhibitory activity and exhibiting 30.60\%, $41.80 \%$, and $71.20 \%$ cell growth inhibition was statistically significant at the concentration of $200(\mathrm{mg} / \mathrm{kg}), 400$ $(\mathrm{mg} / \mathrm{kg})$ extract, and $0.3(\mathrm{mg} / \mathrm{kg})$ vincristine sulfate as a standard drug respectively shown in Fig. 2.

\section{Apoptosis measurement by DAPI staining}

DAPI staining was executed to detect the morphological alterations of apoptotic cells at the end of the 6 days of treatment with $C$. album leaf extract and vincristine sulfate. The apoptotic cells having features including cell shrinkage, membrane blebbing, accumulation of apoptotic bodies, chromatin condensation, and luminously stained nucleus under blue fluorescence were explored for experimental groups in comparison to less luminously stained and round-shaped controlled group cells shown in Fig. 3a. After the 6 days of treatment with plant extract at the concentration of $200 \mathrm{mg} / \mathrm{kg}, 400 \mathrm{mg} /$ $\mathrm{kg}$ and $0.3 \mathrm{mg} / \mathrm{kg}$ vincristine sulfate, we observed $37.5 \pm$ $6.22,54.67 \pm 4.76$, and $82.17 \pm 6.67$ apoptotic cells respectively that were compared with the control group that showed $26 \pm 3.90$ apoptotic cells in Fig. 3b, the data were statistically significant $P<0.001{ }^{(* * *)}$ that increased the number of apoptotic cells.

\section{Measurement of mean survival time and average tumor weight}

The MST and \% ILS of EAC cell bearing Swiss mice were prolonged after 15 days of treatment with C. album leaf extract. After the treatment of 15 days with plant extract at concentration of $400(\mathrm{mg} / \mathrm{kg}), 200(\mathrm{mg} / \mathrm{kg})$, and $0.3(\mathrm{mg} / \mathrm{kg})$ vincristine sulfate, we observed that the MST was $11.33 \pm 2.42$, $9.17 \pm 2.48,14.33 \pm 1.21$ days respectively and compared with control group that showed $7.5 \pm 1.87$ days and percentage increase in life span (\% ILS) $51.07 \%, 22.27 \%, 91.06 \%$ respectively as shown in

\begin{tabular}{|c|c|}
\hline Concentration $(\mathrm{mg} / \mathrm{kg})$ & $\%$ of Mortality \\
\hline 100 & 0 \\
\hline 200 & 0 \\
\hline 400 & 0 \\
\hline 800 & 0 \\
\hline 1600 & 0 \\
\hline 3200 & 16.67 \\
\hline
\end{tabular}

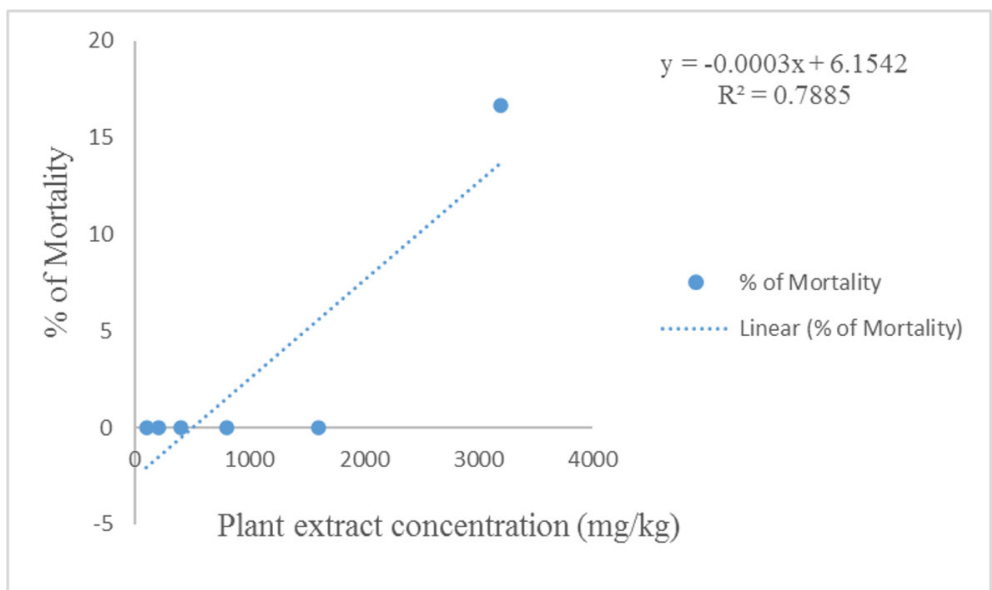

Fig. $1 L_{50}$ value of Chenopodium album leaf extract on Swiss albino mice 


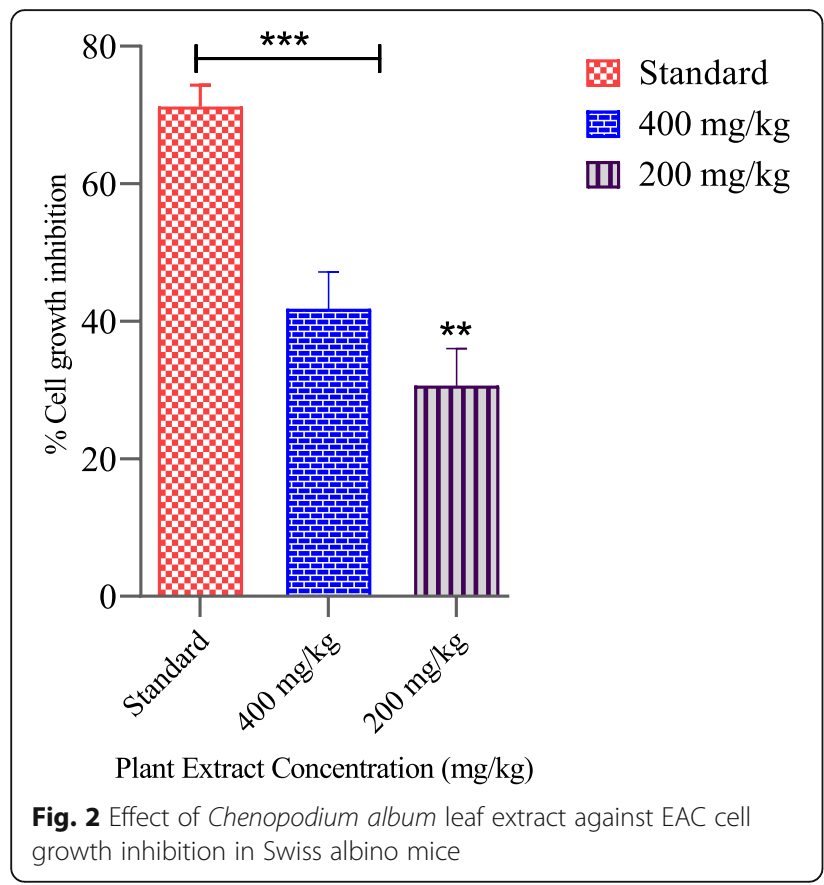

Fig. $4 \mathrm{a}$ and $\mathrm{b}$, the data were statistically significant $P<$ $0.01(*)$. At the same time, after treatment of 15 days with plant extract at the concentration of $200(\mathrm{mg} / \mathrm{kg}), 400$ $(\mathrm{mg} / \mathrm{kg})$, and $0.3(\mathrm{mg} / \mathrm{kg})$ vincristine sulfate, the mean tumor weight of EAC cells bearing Swiss albino mice were $18.50 \pm 2.59 \mathrm{~g}, 13.67 \pm 2.25 \mathrm{~g}, 8.83 \pm 1.47$ g respectively that compared with the control group showed $19 \pm 2.37 \mathrm{~g}$ in Fig. 5 , the data were statistically significant $P<0.01(* *)$. After the treatment with plant extract and standard drug, the size of EAC cell bearing mice was reduced as compared to the control group shown in Fig. 6.

\section{Monitoring of the hematological parameters}

On the 7th day, biochemical profiles of cancerous mice exhibited significant changes in comparison to mice of the control group (Table 1). The hemoglobin content and total RBC count were found to decrease with an increase of total WBC count. After the 6 days of treatment with C. album leaf extract, these parameters were found to be restored toward normal levels. Chenopodium album leaf extract at the concentration of $200(\mathrm{mg} / \mathrm{kg})$,

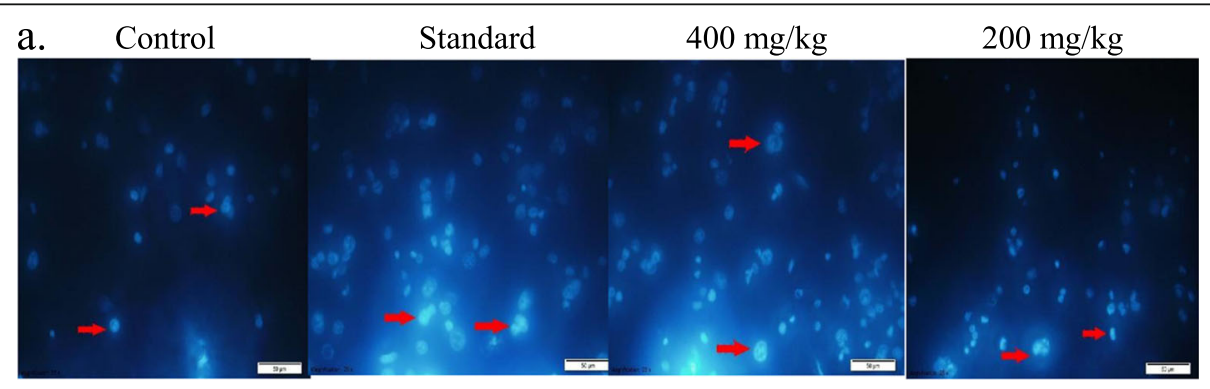

b.

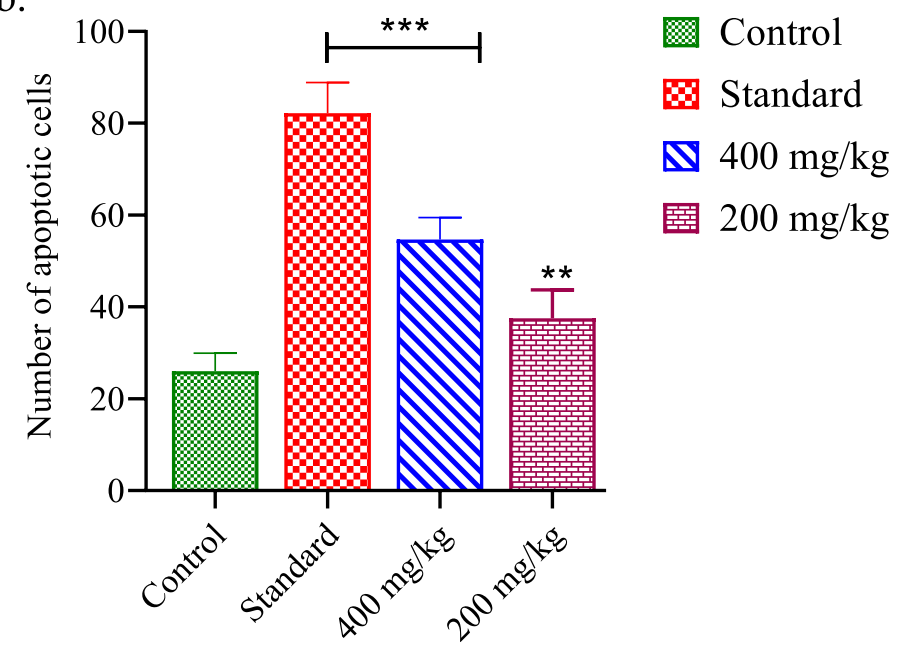

Plant Extract Concentration (mg/kg)

Fig. 3 a Detection of apoptotic cells using DAPI staining after treatment with Chenopodium album leaf extract in EAC cell bearing Swiss albino mice. $\mathbf{b}$ The number of apoptotic cells per slide was estimated by counting apoptotic cells after 6 days of treatment with Chenopodium album leaf extract in EAC cell bearing Swiss albino mice 


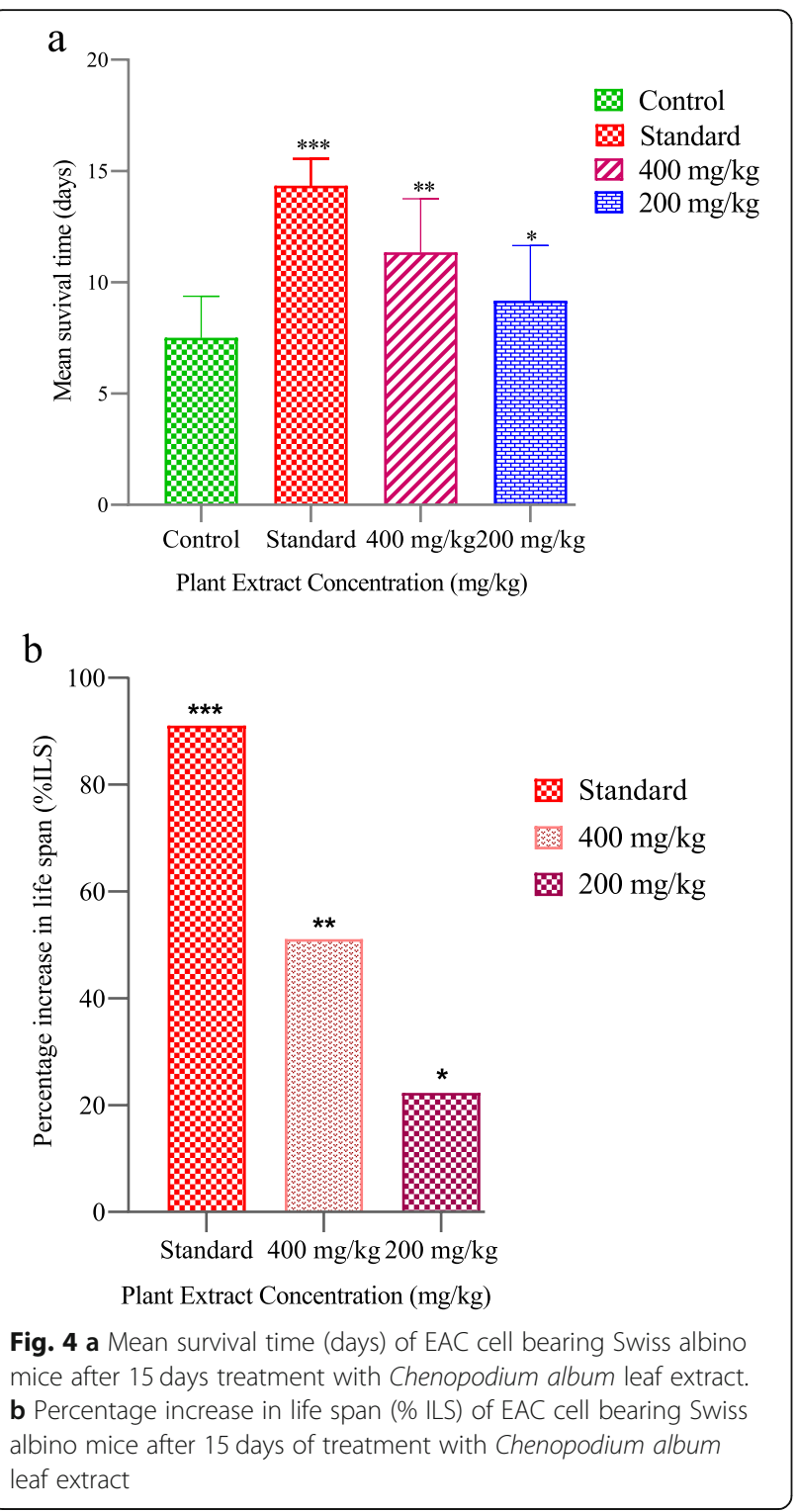

$400(\mathrm{mg} / \mathrm{kg})$, and $0.3(\mathrm{mg} / \mathrm{kg})$ vincristine sulfate restored all the biochemical parameters like hemoglobin, RBC, and WBC to the normal level significantly shown in Table 1 , the data were statistically significant $P<0.001$ (***).

\section{Brine shrimp lethality bioassay}

The median lethal concentration $\left(\mathrm{LC}_{50}\right)$ of the brine shrimp lethality bioassay obtained for C. album leaf extract is $28.10(\mu \mathrm{g} / \mathrm{mL})$ as shown in Fig. 7. The C. album leaf extract at the concentration of $28.10(\mu \mathrm{g} / \mathrm{mL})$ exhibited significant toxicity toward brine shrimps. This may indicate potent cytotoxicity toward tumor cells.

\section{Discussion}

Now, pharmaceutical companies and scientific communities are focusing to explore bioactive phytochemicals

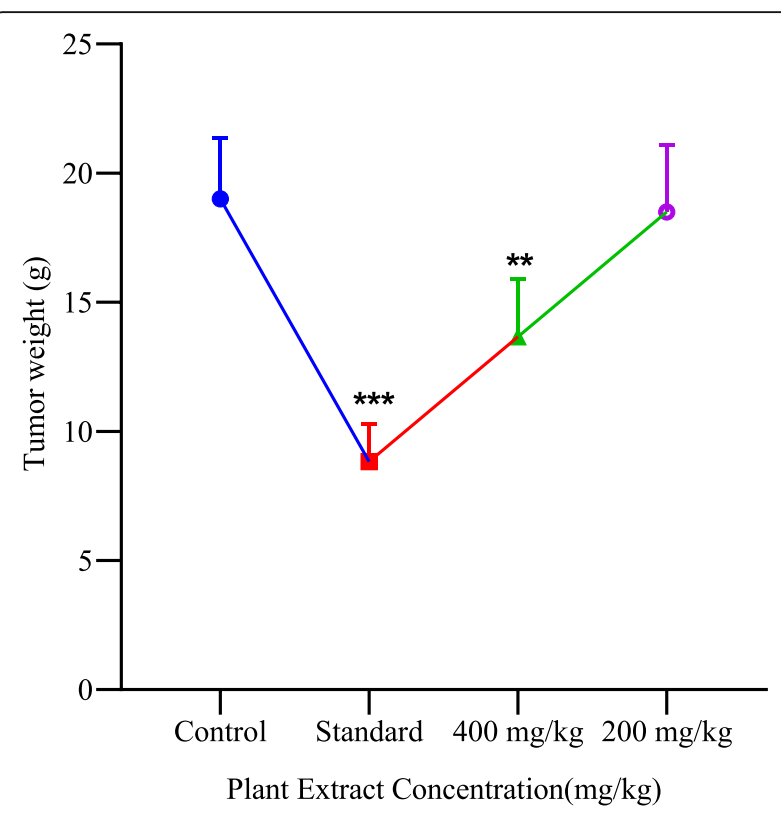

Fig. 5 Tumor weight ( $g$ ) of EAC cell bearing Swiss albino mice after 15 days of treatment with Chenopodium album leaf extract

that are having health benefits with no or less toxicity. The amalgamation of both natural sources of antitumor bioactive constituents with chemotherapeutic agents as like polyphenols that may play a significant role to overcome anticancer drug resistance. In normal living cells, a large number of reactive oxygen species (ROS) may accelerate different events that may cause cancer by fluctuating gene expression and signals of cells. The dietary antioxidants containing supplements derived from natural sources play a significant anticancer role either by counter regulating elevated ROS levels by antioxidation process or by the induction of programmed cell death. The unwanted cellular oxidation can be omitted throughout the uptaking of antioxidants rich dietary supplements [2].

The experiment is designed to investigate anticancer and cytotoxic potentials of $C$. album leaf extract against Ehrlich ascites carcinoma (EAC) cells in Swiss albino mice through growth inhibition of EAC cells, apoptosis by DAPI staining, \% increase of life span, average tumor weight, and brine shrimp lethality bioassay technique respectively. Chenopodium album is a medicinal plant of the Chenopodium genus. Medicinal plants of the Chenopodium genus having a large number of polyphenols including gallic acid, p-hydroxybenzoic acid, vanillic acid, syringic acid, o and p-Coumaric acid, and kempferol. As a result of having a high quantity and number of polyphenols of $C$. album leaf extract, we may suggest that it showed antioxidant and anticancer activity [12, 13]. There are two types of cell death including apoptosis and necrosis, and apoptosis is a perfect way for programmed cell death; by this process, the body specifically 

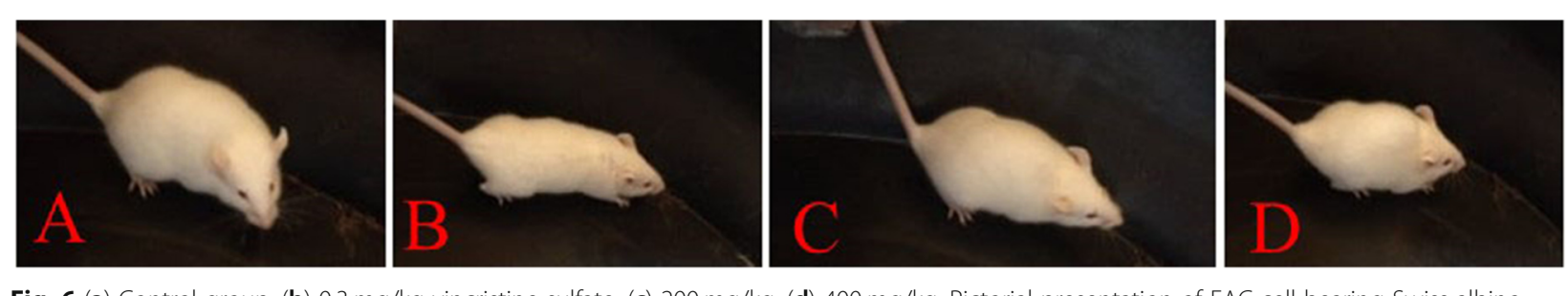

Fig. 6 (a) Control group, (b) $0.3 \mathrm{mg} / \mathrm{kg}$ vincristine sulfate, (c) $200 \mathrm{mg} / \mathrm{kg}$, (d) $400 \mathrm{mg} / \mathrm{kg}$. Pictorial presentation of EAC cell bearing Swiss albino mice after treating with Chenopodium album leaf extract at concentration 200 (mg/kg), 400 (mg/ $/ \mathrm{kg})$, and standard drug 0.3 (mg/kg) vincristine sulfate (VS) and with the increasing of the dose the tumor bearing mice size and weight was reduced that indicate dose dependence

removes unhealthy cells and the normal cells of surrounding remain unaffected. During tumor development, the apoptosis process would be inhibited consequently and the normal living cells undergo abnormal proliferation and as a result, cancer may develop [14]. For almost every type of cancer prevention and treatment, the advancement of apoptosis is necessary. DAPI staining study and Trypan blue dye exhibited the growth inhibitory activity of $C$. album leaf extract on EAC cells through the initiation of apoptosis. Viable EAC cell reduction was found to be around $41.40 \%$ at concentration $400(\mathrm{mg} / \mathrm{kg})$, exhibiting statistically significant growth inhibition properties of $C$. album extracts on cancer cells. The dose-dependent abatement of EAC cells may occur due to the induction of the apoptosis pathway which controls the death of abnormal cells [15]. DAPI staining confirmed the crucial morphological characteristics of the apoptotic cells such as cell shrinking, membrane blebbing, nuclear atomization, chromosome condensation, and accumulation of apoptotic bodies. Cell shrinkage and membrane blebbing are accounted to be the crucial morphological modifications of initial apoptotic cells. Where fragmentation of DNA and apoptotic bodies aggregation are the ultimate products of apoptosis [9], the number of apoptotic cells was found to be increased by around $54.67 \pm 4.76$ at the concentration of $400 \mathrm{mg} / \mathrm{kg}$ (Fig. 2b) and the obtained data is dose dependent, significant data were found after the enlargement of dose as like $400 \mathrm{mg} / \mathrm{kg}$.

All the data of this experiment including cell growth inhibition, lessening of tumor weight, improvement of lifespan, increased number of apoptotic cells, and hematological profile indicated C. album leaf extract as a potent anticancer agent. The effectiveness of the $C$. album leaf extract was compared with a clinically used anticancer drug vincristine sulfate at the concentration of $0.3(\mathrm{mg} / \mathrm{kg})$ intraperitoneally (i.p.). The treatment of EAC cell bearing Swiss albino mice with extract reduced tumor weight and burden $13.67 \pm 2.25 \mathrm{~g}$ at concentration $400(\mathrm{mg} / \mathrm{kg})$ whereas $8.83 \pm 1.47 \mathrm{~g}$ at concentration $0.3 \mathrm{mg} / \mathrm{kg}$ vincristine sulfate respectively. The plant extract at dose $400(\mathrm{mg} / \mathrm{kg})$ improved the life span of cancerous mice and exhibited $51.07 \%$. With the increase of the concentration of extract, the life span of the cancerous mice also increased. Plants that increased the life span of cancerous mice may be a crucial parameter for selecting a plant to treat cancer [16]. This experiment was conducted through the concentration at $200(\mathrm{mg} /$ $\mathrm{kg})$ and $400(\mathrm{mg} / \mathrm{kg})$ to identify the anticancer potency of $C$. album leaf extract at a lower concentration.

At the time of chemotherapy of cancer patients, some fatal problems were observed such as myelosuppression and anemia [17]. Anemia confronted in tumor-bearing Swiss albino mice as a result of the decreased number of red blood cells and hemoglobin content [18]. Treatment with $C$. album leaf extract restored all the biochemical parameters like red blood cells, white blood cells, and hemoglobin content to hematological parameters of normal mice. These parameters indicate that the C. album leaf extract possesses a protective effect on the hematopoietic system.

\section{Conclusion}

In conclusion, the present experiment, for the first time screened in vivo anticancer activity of $C$. album leaf extract on EAC cell bearing Swiss albino mice. Our obtained data may suggest that the treatment of EAC cell bearing Swiss albino mice with $C$. album leaf extract

Table 1 Effect of Chenopodium album leaf extract on EAC cell bearing Swiss albino mice to restore all the biochemical parameters after 6 days of treatment

\begin{tabular}{llll}
\hline Treatment groups & $\mathrm{RBC}\left(\times 10^{9} \mathrm{cells} / \mathrm{mL}\right)$ & WBC $\left(\times 10^{6} \mathrm{cells} / \mathrm{mL}\right)$ & $\% \mathrm{of} \mathrm{Hb}(\mathrm{gm} / \mathrm{dL})$ \\
\hline Control mice (EAC bearing) & $2.4 \pm 0.548$ & $24.8 \pm 0.837$ & $4.4 \pm 0.894$ \\
Standard (vincristine sulfate) & $5.6 \pm 0.548^{* * *}$ & $9.2 \pm 0.864^{* * *}$ & $10.8 \pm 0.842^{* * *}$ \\
$400 \mathrm{mg} / \mathrm{kg}$ & $3.8 \pm 0.745^{* *}$ & $17.2 \pm 0.045^{* * *}$ & $6.2 \pm 0.065^{*}$ \\
$200 \mathrm{mg} / \mathrm{kg}$ & $2.6 \pm 0.548$ & $23.4 \pm 0.320^{*}$ & $4.8 \pm 0.832$ \\
\hline
\end{tabular}




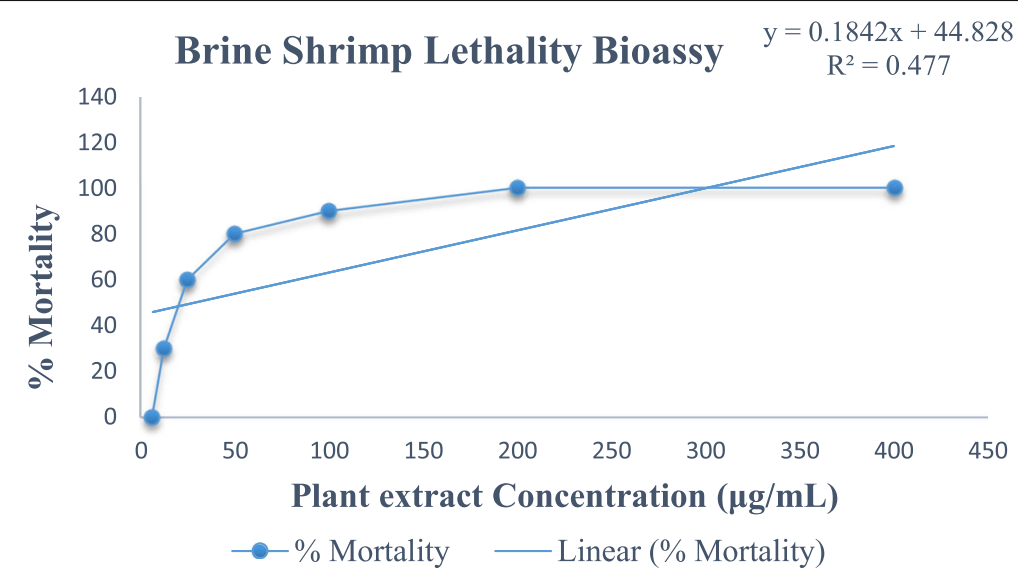

Fig. 7 Brine shrimp lethality bioassay of Chenopodium album leaf extract

inhibited the growth of tumor cells by the induction of apoptosis. The plant extract may contain various kinds of polyphenols, as a result, it may show growth inhibition of cells, provocation of apoptosis, increased life span and lowered tumor weight, and also restored all the biochemical parameters to a normal level significantly. However, the entire mechanism of curative properties of leaf extract such as cytotoxicity needs to examine for the development of potent combinational therapy against various cancer treatments and also need to purify the bioactive phytochemicals of it. Chenopodium album may be a potent anticancer drug for future research and cancer treatment.

\section{Abbreviations}

EAC: Ehrlich ascites carcinoma; C. album: Chenopodium album; RBC: Red blood cells; WBC: White blood cells; DAPI: 4', 6-diamidino-2-phenylindole; DMSO: Dimethylsulfoxide; LD $_{50}$ : Median lethal dose; ANOVA: One-way analysis of variance; PBS: Phosphate-buffered saline; $I_{50}$ : Median lethal concentration; i.p.: Intraperitoneally; MST: Mean survival time; \% ILS: Percent increase of life span

\section{Acknowledgements}

The authors are grateful to Dr. Md. Abu Reza, Protein Science Lab, Department of Genetic Engineering and Biotechnology, University of Rajshahi, Rajshahi 6205, Bangladesh, for providing Ehrlich ascites carcinoma (EAC) cell line and laboratory support.

\section{Collection and identification of plant material}

The leaves were identified and authenticated by the Naimur Rhaman (taxonomist and senior scientific officer at National Herbarium, Dhaka, Bangladesh). Accession number for the plant is 46989 .

\section{Authors' contributions}

"SR': Concept, performed laboratory experiments, statistical analysis with graph, and prepared the final manuscript. SR $R^{2}$ Concept and performed laboratory experiments. SS: Performed laboratory experiments, statistical analysis, and prepared manuscript. TKB: Performed cell growth inhibition and apoptosis by DAPI staining. AKH and SP: Performed cell growth inhibition and statistical analysis with graph. KM: Supervised and monitored all the experiments and activities. All authors read and approved the final manuscript.

\section{Funding}

The study was done through self-finance.

\section{Availability of data and materials}

All data and materials are available upon request.

Ethics approval and consent to participate

The study protocol was approved by the institutional animal ethical committee of Jashore University of Science and Technology, Jashore, Bangladesh. This research work was approved by the Ethical Review Committee of Research cell of Jashore University of Science and Technology, Jashore-7408, Bangladesh (Ref: ERC/FBS/JUST/2019-16).

\section{Consent for publication}

Not applicable.

\section{Competing interests}

The authors declare that they have no competing interests.

\section{Author details}

'Department of Pharmacy, Faculty of Biological Science and Technology, Jashore University of Science and Technology, Jashore 7400, Bangladesh. ${ }^{2}$ Bachelor of Medicine and Bachelor of Surgery, Ad-din Sakina Medical College, Jashore 7402, Bangladesh. ${ }^{3}$ Department of Pharmacy, Faculty of Biological Science and Technology, Jashore University of Science and Technology, Jashore 7408, Bangladesh. ${ }^{4}$ Department of Pharmacy, State University of Bangladesh, Dhaka, Bangladesh. ${ }^{5}$ Department of Pharmacy, East West University, Dhaka, Bangladesh.

Received: 5 May 2020 Accepted: 17 August 2020

Published online: 22 September 2020

\section{References}

1. Zainal B, Abdah MA, Yun HTY, Roslida AH, Rosmin K (2014) In vitro antioxidant and antiproliferative activities of methanolic plant part extracts of Theobroma cacao. Molecules 19:18317-18331

2. M. Abdulla AM, Jamiatul H, Masuda K, Rubait H, Kamruzzaman M, Hoque KMF, M. Abu R, Ferdousi Z (2016) Assessment of antioxidant, anticancer and antimicrobial activity of two vegetable species of Amaranthus in Bangladesh. BMC Comp Alter Med 16:157

3. Choudhary SP, Sharma DK (2014) Bioactive constituents, phytochemical and pharmacological properties of Chenopodium album: a miracle weed. Inter J Pharmacogn 1:545-552

4. Renata N, Katarzyna S, Urszula G D, Jolanta R, ukasz K L (2016) Antioxidative and cytotoxic potential of some Chenopodium L. species growing in Poland. Sau J Bio Sci 23:15-23.

5. Ali A, Javaid A, Shoaib A (2017) GC-MS analysis and antifungal activity of methanolic root extract of Chenopodium album against sclerotium rolfsii. Planta Daninha 35

6. Menka K, Ojeswi BK, Bhavna S, Man MS (2009) Chenopodium album prevents progression of cell growth and enhances cell toxicity in human breast cancer cell lines. Oxida Med Cell Long 2:160-165 
7. Ali EAS (2015) The chemical constituents and pharmacological effects of Chenopodium album - an overview. Inter J Pharma Screen M 5:10-17

8. Litchfield JT, Wilcoxon F (1949) A simplified method of evaluating doseeffect experiments. J. Pharmacol. Exp. Ther 96:99-113

9. Farhadul I, Hasina K, Mahbuba K (2014) Growth inhibition and apoptosis of Ehrlich ascites carcinoma cells by the methanol extract of Eucalyptus camaldulensis. Pharma Biology 52:281-290

10. Samiron S, Sohel R, Shakila R (2018) Evaluation of anticancer properties against Ehrlich ascites carcinoma (EAC) cell line, cytotoxic and analgesic activity of methanol extract of Hibiscus moscheutos in Swiss albino mice. Inter J of Pharma Sci Rev and Res 49:128-134

11. Asaduzzaman M, Sohel RM, Raqibul HSM, Monir H, Nittananda D (2015) Cytotoxic (brine shrimp lethality bioassay) and antioxidant investigation of Barrngtonia acutangula (L.). Int J Phar Sci Res 6:119-1185

12. Renata N, Katarzyna S, Urszula GD (2016) Antioxidative and cytotoxic potential of some Chenopodium L. species growing in Poland. Saudi J Biol Sci 23:15-23

13. Urszula GD, Michał S, Maciej S (2013) Antioxidant and anticancer activities of Chenopodium quinoa leaves extracts - in vitro study. Food Chem Tox 57: 154-160

14. Brown JM, Attardi LD (2005) The role of apoptosis in cancer development and treatment response. Nat Rev Cancer 5:231-237

15. Fadeel B, Orrenius S (2005) Apoptosis: a basic biological phenomenon with wide ranging implications in human disease. J Intern Med 258:479-517

16. Price VE, Greenfield RE (1958) Anemia in cancer. Adv Cancer Res 5:199-200

17. Hirsch J (2006) An anniversary for cancer chemotherapy. JAMA 296:15181520

18. Hogland HC (1982) Hematological complications of cancer chemotherapy Semin Oncol 9:95-102

\section{Publisher's Note}

Springer Nature remains neutral with regard to jurisdictional claims in published maps and institutional affiliations.

\section{Submit your manuscript to a SpringerOpen ${ }^{\circ}$ journal and benefit from:}

- Convenient online submission

- Rigorous peer review

- Open access: articles freely available online

High visibility within the field

- Retaining the copyright to your article

Submit your next manuscript at $\boldsymbol{\nabla}$ springeropen.com 